\title{
LONG-TERM CHANGES IN FISH COMMUNITY STRUCTURE REVEALED BY GILLNET MONITORING IN A SHALLOW, LOWLAND RESERVOIR
}

\author{
Zbigniew KACZKOWSKI* and Piotr FRANKIEWICZ \\ Division of Applied Ecology, University of Łódź, Łódź, Poland
}

\begin{abstract}
Kaczkowski Z., Frankiewicz P. 2017. Long-term changes in the fish community structure revealed by gillnet monitoring in a shallow, lowland reservoir. Acta Ichthyol. Piscat. 47 (3): 279-288.
\end{abstract}

\begin{abstract}
Background. Fish communities can support or hinder water quality management. Sulejów Reservoir, which is situated on the Pilica River in Central Poland, serves as a strategic reserve of drinking water for the Łódź Agglomeration. Precise knowledge of the long-term dynamics of the structure of the fish community, what was the aim of this study, is important for proper management to slow the eutrophication of the reservoir and prevent toxic algal blooms.

Materials and methods. To determine fish species composition, multimesh gill nets with mesh sizes ranging from 11 to $80 \mathrm{~mm}$ were used. From 1993 to 2015, gillnetting was conducted 1-2 times per month from June through November in two representative parts of the reservoir, and principal component analysis (PCA) was applied to explore the temporal variation in fish community structure expressed as the relative contribution of each species to the total fish biomass.

Results. Dominance fluctuated among four species in the fish community: common bream, Abramis brama (Linnaeus, 1758); roach, Rutilus rutilus (Linnaeus, 1758); white bream, Blicca bjoerkna (Linnaeus, 1758); and pike-perch, Sander lucioperca (Linnaeus, 1758). PCA revealed three principal components with eigenvalues larger than one that explained $73.3 \%$ of the observed variance in the temporal changes in fish community composition. A negative correlation was found between pike-perch biomass and roach biomass $(r=0.82)$, while a positive correlation was observed between the biomass of pike-perch and that of common bream $(r=0.73)$. Consequently, there was a highly negative correlation between the biomasses of common bream and roach $(r=0.80)$. Furthermore, an interesting temporal pattern was observed; from 1993 to 2000, the fish community was dominated by common bream and pike-perch but then shifted towards domination by roach and white bream, despite declining phosphorous and carbon concentrations. Recently, this trend has been reversed, and a more balanced fish community structure has been established.

Conclusion. Fish community succession, which is usually reported to be a one-directional process in reservoirs, i.e., from a riverine fish or percid-dominated to a cyprinid (bream)-dominated state, was more ambiguous in Sulejów Reservoir. This was likely a consequence of both restoration issues related to decreasing nutrient loads and the influence of zebra mussel, Dreissena polymorpha invasion on the trophic relations in the reservoir.
\end{abstract}

Keywords: lowland reservoir, roach Rutilus rutilus, common bream Abramis brama, fish community succession, zebra mussel Dreissena polymorpha

\section{INTRODUCTION}

Depending on their species composition, abundance, and age structure, fish communities can support or hinder water quality management (De Backer et al. 2012, Gołdyn et al. 2014), biodiversity conservation (Kruk and Penczak 2003, Kukuła 2003, Paulovits et al. 2014, Ciepłucha et al. 2016) and other valuable ecosystem services, such as the provision of food or leisure (Wołos and Piskorski 1991, Szlakowski and Wiśniewolski 2001, Kaczkowski and Grabowska 2016). Fish communities are especially important in artificially created systems, such as reservoirs, that must usually be managed to reconcile social expectations with conservation or maintenance goals (Zalewski 1998, Starmach and Jelonek 2001, Wagner et. al. 2009, Triest et al. 2016). According to Kubečka (1993), under common conditions in central and eastern Europe, six different types of fish fauna can be expected depending on the successional stage of a reservoir; in the case of shallow lowland reservoirs, such as Sulejów Reservoir (Poland), a cyprinid-dominated fish community should be the anticipated mature ichthyocoenoses (Kubečka 1993). Even though this functional faunal type seems to be common and widespread, information about longterm temporal changes in the fish community structure of shallow and nutrient-rich reservoirs is rather scarce and mostly limited to deeper, canyon-shaped reservoirs (Gido et al. 2000, Scharf 2008, Ř́íha et al. 2009). 
Roach, Rutilus rutilus (Linnaeus, 1758), bream, Abramis brama (Linnaeus, 1758), and white bream, Blicca bjoerkna (Linnaeus, 1758), are the major contributors to cypriniddominated fish communities in combination with a smaller proportion of percids such as perch, Perca fluviatilis Linnaeus, 1758, pike-perch, Sander lucioperca (Linnaeus, 1758), and ruffe, Gymnocephalus cernuus (Linnaeus, 1758). The first two of these percid species are the major target of commercial and recreational fisheries, but in cypriniddominated lakes, they are secondary players in term of their impact on food web dynamics and water quality maintenance. Cyprinid species are more competitive for shared food resources, such as planktonic crustaceans or benthic invertebrates, if compared to perch or other percids (Hrbaček et al. 1986, Persson 1986, Sed'a et al. 1989, Persson and Hansson 1999). Another advantage held by cyprinids is their highly efficient, $r$-selected mode of reproduction combined with typically weak top-down control by predators due to the prolonged omnivory of young perch age classes and widespread overfishing of obligate piscivores such as pike-perch or larger perch specimens (Eero 2004, Allan et al. 2005, Mehner 2010, Psuty 2010).

Two dominant cyprinids, roach and bream, often occur in approximately the same proportions, as presented in the review by Kubečka (1993), which suggests that neither fish was more competitive in the analysed reservoirs. However, numerous detailed life-trait studies show that each species has different adaptive traits influencing their competitive skills. Roach are much more flexible in terms of the location of their spawning grounds, being able to utilize even small tributaries and to tolerate a wider range of spawning substrates. In turn, bream are theoretically more efficient at utilizing different food sources, such as benthos or zooplankton, and their high-backed bodies deter predation. Furthermore, as a multiple spawner, the species can better overcome short-term, unfavourable environmental conditions (Pivnička and Švátora 1977, van den Berg 1993, Mann 1996, Nagelkerke and Sibbing 1996, Kakareko 2001, Prus 2009, Targońska et al. 2014). As a result, short-term fluctuations in the populations of these two species should be expected.

The main objective of this study was to investigate the structure of the fish community in Sulejów Reservoir, Central Poland, over a 20-year period. We addressed the following questions:

- To what extent does the structure of the fish community in Sulejów Reservoir follow the pattern presented by Kubečka (1993)?

- What are the possible reasons for differences, if any are observed, between the Sulejów fish community and the model faunal type in Kubečka (1993)?

- Are there any correlations between roach, common bream and pike-perch biomass and eutrophication indices (i.e., the concentrations of phosphorous and total organic carbon)?

\section{STUDY AREA}

Sulejów Reservoir is a shallow, lowland reservoir located along the middle course of the Pilica River in central Poland. The maximum length of the reservoir is $15.5 \mathrm{~km}$, and the maximum width is $2.1 \mathrm{~km}$. At maximum capacity $\left(75 \times 10^{6} \mathrm{~m}^{3}\right)$, the reservoir covers $22 \mathrm{~km}^{2}$ with a mean depth of $3.3 \mathrm{~m}$ and a maximum depth of $11 \mathrm{~m}$. The shoreline is approximately $54 \mathrm{~km}$ in length, and the mean water retention time of the reservoir is 30 days. The floodplain and banks are principally forested and covered by shrubs, but large areas of the floodplain are used for agriculture, which adversely impacts the quality of the water. Due to high water level fluctuations, the littoral zone is almost devoid of macrophytes, but in the sparsely vegetated lacustrine parts of the reservoir, the following macrophytes are usually found: Potamogeton lucens, Polygonum amphibium, Elodea canadensis, Galium palustre, Carex acuta, Equisetum fluviatile, Eleocharis palustris, Glyceria fluitans, and Iris pseudoacorus (see Wojtal et al. 2003, Wojtal-Frankiewicz et al. 2015).

Sulejów Reservoir is an eutrophic ecosystem; the mean total phosphorus concentration at spring overturn during the study period was approximately $190 \mu \mathrm{g} \cdot \mathrm{L}^{-1}$ (ranging from $43 \mu \mathrm{g} \cdot \mathrm{L}^{-1}$ in 2009 to $1.03 \mathrm{mg} \cdot \mathrm{L}^{-1}$ in 1995), and the mean summer concentration of total organic carbon was approximately $11.6 \mathrm{mg} \cdot \mathrm{L}^{-1}$ (ranging from $6.88 \mu \mathrm{g} \cdot \mathrm{L}^{-1}$ in 2006 to $29.05 \mathrm{mg} \cdot \mathrm{L}^{-1}$ in 1994). Under such conditions, summer blooms of cyanobacteria (mainly Microcystis aeruginosa and Aphanizomenon flos-aquae have frequently been observed. The mean chlorophyll concentration during the growing seasons was approximately $30 \mu \mathrm{g} \cdot \mathrm{L}^{-1}$, but it can exceed $100 \mu \mathrm{g} \cdot \mathrm{dm}^{-3}$ during phytoplankton blooms (Wagner et al. 2009). Since 1993, the mean summer biomass of zooplankton sampled in the pelagic zone has ranged from $4 \mathrm{mg} \cdot \mathrm{L}^{-1}$ to $15 \mathrm{mg} \cdot \mathrm{L}^{-1}$ and has primarily consisted of the following cladocerans: Daphnia cucullata, Daphnia longispina, Leptodora kindtii, and Bosmina coregoni, but biomass peaks up to $60 \mathrm{mg} \cdot \mathrm{L}^{-1}$ exclusively due to a high abundance of Bosmina coregoni, have been observed (Wojtal et al. 2004, Wojtal-Frankiewicz et al. 2015).

In the early 1990s, a significant episode in terms of the ecological status of the reservoir occurred; the invasion of the zebra mussel, Dreissena polymorpha resulted in the establishment of a dense population that reached up to 8000 specimens per $1 \mathrm{~m}^{2}$ from 1996-1999 (AbraszewskaKowalczyk et al. 1999).

\section{MATERIALS AND METHODS}

Fish collection. Multimesh gill nets with mesh sizes from 11 to $80 \mathrm{~mm}$ were used to determine fish species composition. Identical nets, each $77 \mathrm{~m}$ long and $3 \mathrm{~m}$ high and consisting of 11 different 7-m long panels (mesh panel size from knot to knot and order: 11, 24, 50, 60, 30, 70, 35, $80,40,20$, and $16 \mathrm{~mm}$ ), were used for sampling. Fish aged 1 year and above were considered in this study. Gillnetting was conducted 1-2 times per month from June through November at two sites of the reservoir (Karolinów and Bronisławów) (Fig. 1). At each sampling time, the precise location of the sampling areas mostly depended on wind condition (strength and direction) as well as the water level of the reservoir (gillnetting only at standard water 


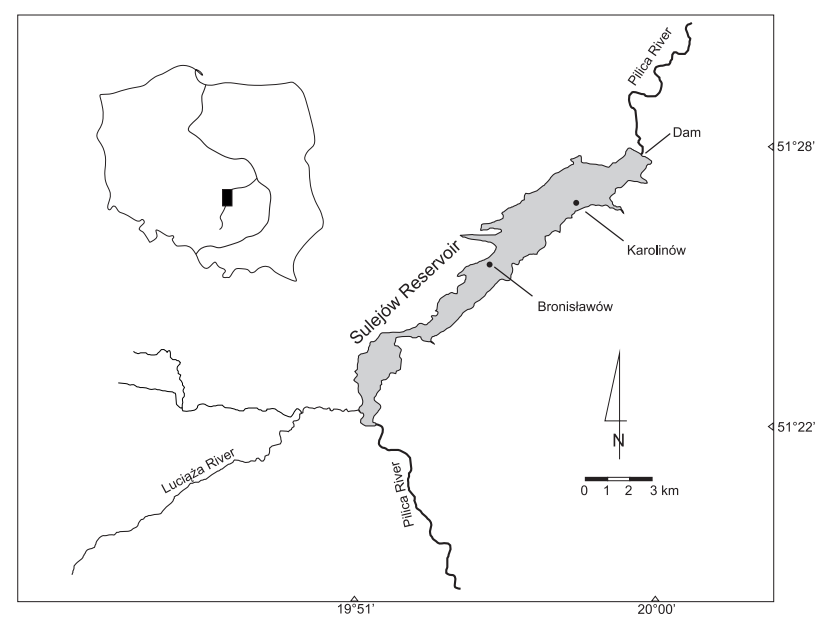

Fig. 1. Location of Sulejów Reservoir at the Pilica River, Poland with multimesh gillnet station distribution (Karolinów and Bronisławów)

level i.e., $\pm 166.60 \mathrm{~m}$ above the sea level) and the fishing pressure from anglers and other fishermen. Nets were set in the water from dusk to the dawn, and the collected fish were measured (total length, TL) and weighed to the nearest centimetre and gram, respectively. Then, the cumulative biomass of each species from all catches was calculated for each year.

Water chemistry data collection. The total phosphorous (TP) and total organic carbon (TOC) concentrations in Sulejów Reservoir were obtained from routine surface water environmental monitoring by the Regional Inspectorate for Environmental Protection in Łódź.

Data analysis. A principal component analysis (PCA) was applied to determine the long-term pattern of changes of the structure of the fish community in Sulejów Reservoir using arcsine-transformed data. Species whose share in the total fish biomass exceeded 5\% in at least in one year were considered in this analysis. Regression analysis was used to assess the temporal changes in the relative biomass of the dominant fish species. All calculations were performed in Statistica 10 (StatSoft).

\section{RESULTS}

Gillnet surveys regularly conducted since 1993 have shown fluctuating dominance among four species in the fish community (Fig. 2). These included three cyprinid species, the common bream, roach, and white bream, and a piscivorous percid species, the pike-perch. Other fish species that were regularly found in gillnet catches included perch, bleak, Alburnus alburnus (Linnaeus, 1758), ruffe, ide, Leuciscus idus (Linnaeus, 1758), asp, Leuciscus aspius (Linnaeus, 1758), northern pike, Esox lucius Linnaeus, 1758, and wels catfish, Silurus glanis Linnaeus, 1758 (Table 1).

Principal component analysis revealed three components with eigenvalues greater than one, and the first two PCs explained approximately $59 \%$ of the observed variance in the composition of the fish community and the concentrations of phosphorous and carbon (Table 2).
The biomasses of common bream, pike-perch, and asp as well as the phosphorus and carbon concentrations were negatively correlated with the first $\mathrm{PC}$, while roach and white bream were positively correlated (Fig. 3, Table 2). Additionally, white bream had the highest negative loading while pike had the highest positive loading with the second PC.

Only the two first components with the highest eigenvalues were plotted for analysing the fish community composition as including other factors did not provide any additional significant information for interpreting the data. A negative relation was found between the biomasses of pike-perch and roach $(r=0.82, P<0.0001)$ (Fig. 3), but there was a positive relation between the biomass of pike-perch and the biomass of common bream $(r=0.73$, $P<0.0001)$. Consequently, there was a highly negative relation between the biomass of common bream and that of roach $(r=0.80, P<0.0001)$. An interesting temporal pattern emerged from the PCA (Fig. 4); from 1993 through 2000, the fish community was dominated by common bream and pike-perch but then shifted towards roach and white bream domination, despite a decline in phosphorous and carbon concentrations. Recently, this trend has been reversed, and a more balanced fish community structure has been established.

\section{DISCUSSION}

The first theoretical ichthyocoenose models bound community shifts with trophic status, but they were developed for northern, initially oligotrophic, temperate lakes (Colby et al. 1972, Prejs 1978, 1984) and thus were not appropriate for European reservoirs, as concluded by Kubečka (1993). Reservoirs can be eutrophicated from the moment of their origin, the biotic interactions are more complex and influenced by more dynamic hydrological regimes and management practices than in natural lakes (Hrbaček 1984, Straškraba 1998, Wagner et al. 2009). As a result, at least six characteristic fish faunal types have been distinguished among European impoundments (Kubečka 1993), and Sulejów Reservoir seems to fit the cyprinid-dominated faunal type, which is one of the most frequent lowland reservoir ichthyocoenoses (Kubečka 1993). According to the general model of the cyprinid-dominated faunal type, roach, common bream, and white bream constitute the major part of the fish biomass, and common bream is the most abundant, even though roach often occur in approximately the same proportions, as highlighted by Kubečka (1993). Similar results showing fish community dominance of the common bream were obtain for many Polish large reservoirs, e.g., Jeziorsko (Andrzejewski and Mastyński 2004), Zegrzyński (Wiśniewolski 2002, Wiśniewolski et. al. 2004), Włocławek (Wiśniewolski 2002), and Goczałkowice (Epler et al. 2005). However, contradictory results were obtained for Solina Reservoir (Wiśniewolski et. al. 2009) and in the presently reported study, in which roach had a higher biomass than common bream in Sulejów Reservoir.

A long-term data set shows a more complicated pattern for Sulejów Reservoir with bream dominance persisting until the end of the 1990s, after which the abundance of 

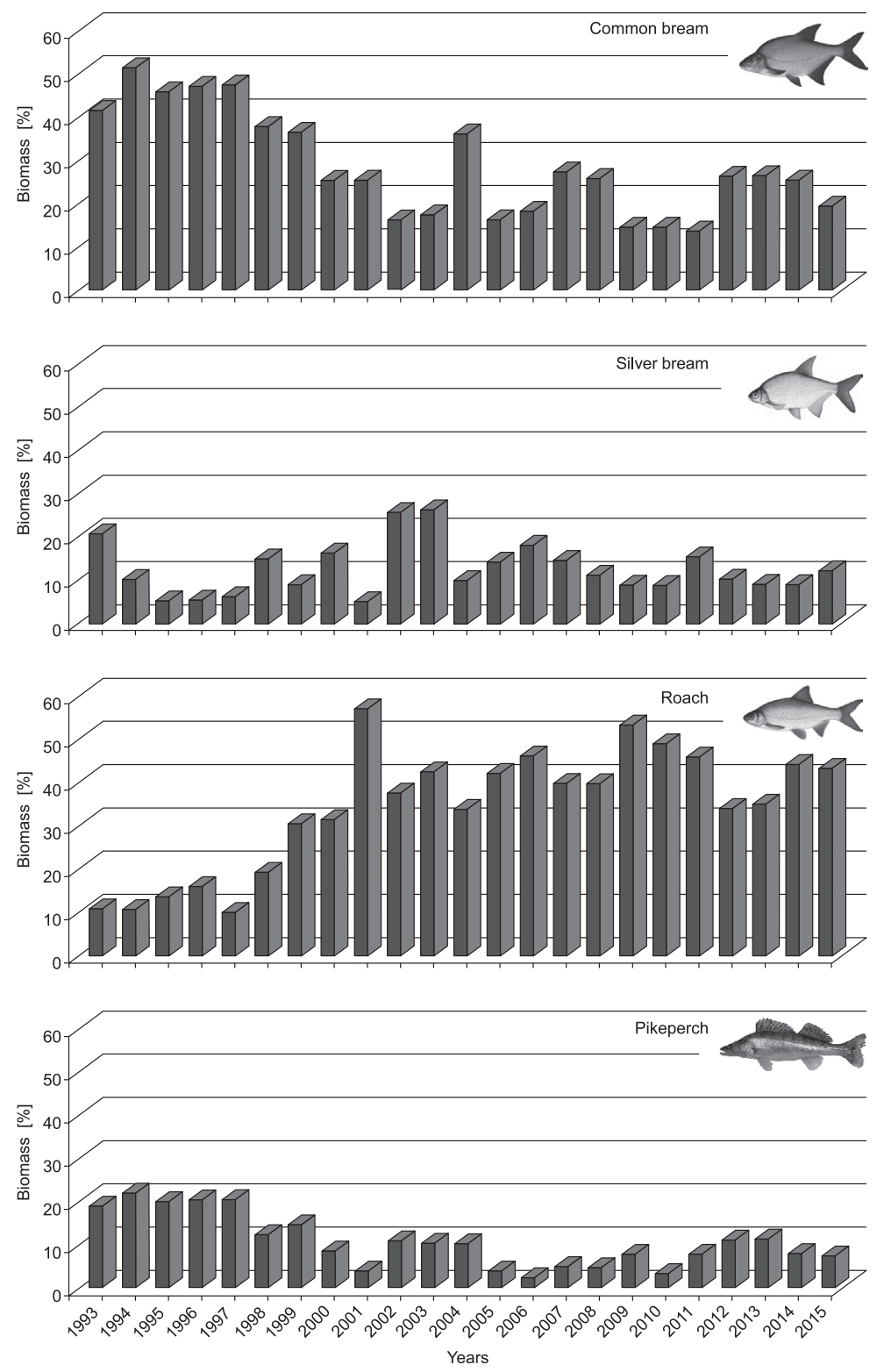

Fig. 2. Share of the dominated fish species in the total biomass of multimesh gill net catches in Sulejów Reservoir within 1993-2015

roach in gill net samples began to grow before reaching double or even triple the biomass of common bream over the next decade (Fig. 2). The explanation for this phenomenon might be the colonization of the reservoir by the non-native bivalve the zebra mussel, Dreissena polymorpha, which was reported in the lake beginning in the mid-1990s (Abraszewska-Kowalczyk et al. 1999). Among the commonly occurring fish species in Sulejów Reservoir, only roach was able to crush a wide range of Dreissena mussels and effectively utilize this new food resource (Prejs et al. 1990, van den Berg 1993, Nagelkerke and Sibbing 1996, Molloy et al. 1997, Kobak et al. 2010), so interspecific food competition could primarily be limited to the smaller specimens $(<15 \mathrm{~cm})$. At this stage, roach mostly competes for zooplankton and chironomids with common and white bream (van den Berg 1993, Nagelkerke and Sibbing 1996, Kakareko 2001, Prus 2009). Roach specimens can switch to feed on zebra mussel much faster $(>160 \mathrm{~mm}$ TL) and more effectively than bream ( $>370 \mathrm{~mm}$ TL), and it is also able to consume much larger mussels (typically 6-18 mm long and a maximum of $19 \mathrm{~mm}$ ) than common bream (typically 6-8 $\mathrm{mm}$ long and a maximum $13 \mathrm{~mm}$ ). Thus, the species can subsequently decrease its food niche overlap with other fish species (Martyniak et al. 1987, Prejs et al. 1990, Nagelkerke and Sibbing 1996, Molloy et al. 1997, Kobak et al. 2010), which could explain the growth of the roach population in the reservoir over time. At the end of the 20th century, mean Dreissena mussel densities in Sulejów Reservoir were estimated at several hundred individuals per $1 \mathrm{~m}^{2}$ with the highest values ranging from 7832 to 8086 individuals per $1 \mathrm{~m}^{2}$ (Abraszewska-Kowalczyk et al. 1999, Stańczykowska et al. 2010), similar to those observed in natural lakes. According to Lewandowski (2001), the mean zebra mussel densities in 16 Masurian lakes exceeded 1000 individuals per $1 \mathrm{~m}^{2}$, with a maximum 
Table 1

List of the fish species (in alphabetic order in every dominance group) and its dominance status recorded in Sulejów Reservoir within 1993-2015

Species and its dominance status

\begin{tabular}{|c|c|}
\hline & Species and its dominance status \\
\hline \multicolumn{2}{|c|}{ Species whose share in the total fish biomass exceeded 5\% in at least one year between 1993-2015 } \\
\hline Asp & Leuciscus aspius (Linnaeus, 1758) \\
\hline Bream & Abramis brama (Linnaeus, 1758) \\
\hline Perch & Perca fluviatilis Linnaeus, 1758 \\
\hline Pike-perch & Sander lucioperca (Linnaeus, 1758) \\
\hline Roach & Rutilus rutilus (Linnaeus, 1758) \\
\hline White bream & Blicca bjoerkna (Linnaeus, 1758) \\
\hline \multicolumn{2}{|c|}{$\begin{array}{l}\text { Species whose share in the total fish biomass exceeded } 1 \% \text {, but less than } 5 \% \text { ), in at least one year or its presence } \\
\text { was noted in at least } 75 \% \text { of gillnetting operations between 1993-2015 }\end{array}$} \\
\hline Bighead carp & Hypophthalmichthys nobilis (Richardson, 1845) \\
\hline Bleak & Alburnus alburnus (Linnaeus, 1758) \\
\hline Carp & Cyprinus carpio Linnaeus, 1758 \\
\hline Ide & Leuciscus idus (Linnaeus, 1758) \\
\hline Pike & Esox lucius Linnaeus, 1758 \\
\hline Rudd & Scardinius erythrophthalmus (Linnaeus, 1758) \\
\hline Ruffe & Gymnocephalus cernuus (Linnaeus, 1758) \\
\hline Sturgeon hybrids & Acipenser sp. \\
\hline Wels catfish & Silurus glanis Linnaeus, 1758 \\
\hline \multicolumn{2}{|r|}{ Species whose share in the total fish biomass never exceeded $1 \%$} \\
\hline Barbel & Barbus barbus (Linnaeus, 1758) \\
\hline Crucian carp & Carassius carassius (Linnaeus, 1758) \\
\hline Dace & Leuciscus leuciscus (Linnaeus, 1758) \\
\hline Prussian carp & Carassius gibelio (Bloch, 1782) \\
\hline Silver carp & Hypophthalmichthys molitrix (Valenciennes, 1844) \\
\hline Tench & Tinca tinca (Linnaeus, 1758) \\
\hline Vimba bream & Vimba vimba (Linnaeus, 1758) \\
\hline
\end{tabular}

of approximately 3500 individuals per $1 \mathrm{~m}^{2}$. In the most hypertrophic locations, the densities dropped below 100 individuals per $1 \mathrm{~m}^{2}$, but they reached densities of 6000 9000 individuals per $1 \mathrm{~m}^{2}$ in the most suitable locations (Lewandowski 2001). In the Szczecin Lagoon, densities of more than one hundred thousand mussels per $1 \mathrm{~m}^{2}$ were reported (Lewandowski 2001, Marchowski et al. 2015).

The presence of Dreissena seems to explain only part of the observed long-term differentiation in the surveyed fish community. The increase in roach biomass was associated with a decline in bream abundance; every "strong" biomass peak of one species was accompanied by an opposing "weak" biomass peak in a second (Fig. 2). Such a relation among two species suggests that they have similar environmental requirements and are competing for key resources, and this has been observed in other species occupying similar niches (e.g., vendace, Coregonus albula (Linnaeus, 1758), and Fontane cisco, Coregonus fontanae Schulz et Freyhof, 2003, in Lake Stechlin; Mehner et al. 2011). Numerous studies show that either roach or common bream gain a competitive advantage depending on the level of eutrophication, while white bream shows an intermediate response (Lammens 1984, van den Berg
1993, Nagelkerke and Sibbing 1996), as was observed in Sulejów Reservoir (Fig. 2). PCA revealed that peaks in common bream biomass in Sulejów Reservoir were positively correlated with increased values of the analysed eutrophication indices (TP, TOC), especially phosphorus levels (TP, $r=0.501, P<0.05$, Fig. 3). This observation seems to be consistent with numerous observations pointing to roach being a more eutrophication-sensitive species; it has a more complex trophic ontogeny with more feeding guild shifts during its life span then bream (roach, with four shifts; bream, with three; Specziar and Rezsu 2009). It is also less competitive when utilizing food resources such as zooplankton (van den Berg 1993) or chironomids (Lammens 1989, Persson and Hansson 1999), but in the absence of zebra mussels, it can shift its diet toward plant food, which becomes less available as lake trophy increases (Prejs 1984, Horpilla 1999). The lower resilience of roach to eutrophication is also evident in the occurrence of piscivores, especially pikeperch. The presence of predators changes the habitat use by groups of different sizes of roach, shifting juvenile refugia from pelagial to littoral areas and limiting the use of the pelagic zone to larger specimens. Consequently, 
Table 2

Summary of the principal component analysis (PCA) of the fish biomasses and the phosphorus and carbon concentrations in Sulejów Reservoir within 1993-2015

\begin{tabular}{lcrrr}
\hline & Factor 1 & Factor 2 & Factor 3 & Factor 4 \\
\hline Eigenvalues & 3.747 & 1.568 & 1.287 & 0.804 \\
\% of total variance & 41.635 & 17.427 & 14.295 & 7.406 \\
Cumulative \% & 41.635 & 59.061 & 73.356 & 82.292 \\
\hline \multicolumn{2}{c}{ Variables load to the factors (based on correlations) } & & \\
\hline Common bream & -0.888 & -0.113 & 0.070 & -0.008 \\
Roach & 0.901 & 0.290 & -0.192 & 0.035 \\
White bream & 0.542 & -0.678 & 0.150 & 0.175 \\
Pike-perch & -0.787 & -0.381 & -0.033 & 0.200 \\
Asp & -0.595 & 0.443 & -0.229 & -0.354 \\
Perch & 0.039 & 0.297 & 0.843 & -0.372 \\
Northern pike & -0.391 & 0.691 & -0.127 & 0.521 \\
Carbon & -0.582 & -0.317 & -0.407 & -0.349 \\
Phosphorus & -0.624 & -0.070 & 0.526 & 0.274 \\
\hline
\end{tabular}

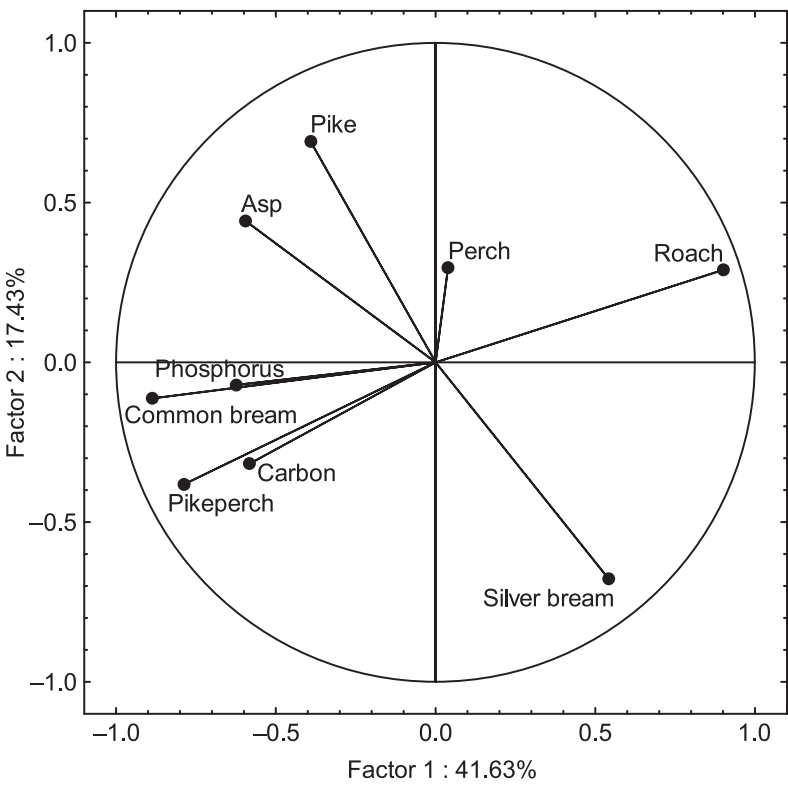

Fig. 3. Results of principal component analysis (PCA) conducted on fish biomass, the phosphorus and carbon concentrations data collected from 1993 to 2015 in Sulejów Reservoir, central Poland; graph presents the projection of variables on the plane defined by the first two PCA factors

roach are susceptible to pike-perch predation in the pelagial and even more susceptible to perch predation in the littoral (Lammens 1989, Brabrand and Faafeng 1993, Frankiewicz et al. 1996, 1999, Frankiewicz 1998). This suggests a negative correlation between roach and pikeperch densities, which was observed in Sulejów Reservoir over the 23-year survey period (Fig. 2). Additionally, high nutrient availability usually results in increased turbidity and the loss of littoral macrophytes, which are an important juvenile roach refuge, reinforcing the vulnerability of roach to predation due to decreased littoral refuge quality

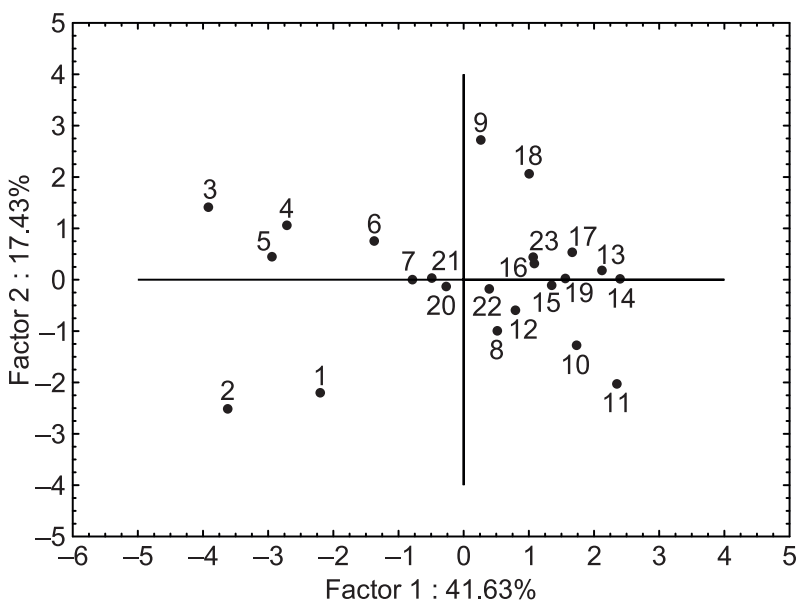

Fig. 4. Results of principal component analysis (PCA) conducted on fish biomass, the phosphorus and carbon concentrations data collected from 1993 to 2015 at Sulejów Reservoir, central Poland; graph presents the projection of the sampling years on the plane defined by the first two PCA factors; the numbers indicate the consecutive years from 1993 (1) to 2015 (23)

(Brabrand and Faafeng 1993). In contrast, only small bream $(<20 \mathrm{~cm})$ are vulnerable to predation, while larger specimens are highly robust against such top down impacts due to their high-backed body shape. Therefore, bream can more successfully coexist with piscivores and increase their foraging efficiency with increasing reservoir trophy, thus benefiting from lower competition for food resources (Lammens 1989). According to the latest findings, external nutrient loading is decreasing due to different conservation practices aimed at mitigating diffuse pollution sources (e.g., establishing riparian buffer zones in agriculture 
areas) upstream of the reservoir (Piniewski et al. 2015). Considering these factors, the reason for the recently reversed trend in bream/roach biomass is unknown, but one potential explanation could be the decrease in the zebra mussel population, a recent phenomenon in Polish lakes due to environmental changes (Stańczykowska et al. 2010). Improved water quality and lower primary productivity (Godlewska et al. 2015, Piniewski et al. 2015) may no longer be able to support large populations of filter feeders such as D. polymorpha, resulting in a declining roach population, a major mussel consumer in the reservoir. Further research is needed to confirm this hypothesis.

In conclusion, the succession of the fish community in Sulejów Reservoir towards roach domination differed from the typical bream-dominated faunal type described by Kubečka (1993) and reported for the majority of Polish reservoirs. The most likely reason for roach domination was primarily the invasion of the zebra mussel (Dreissena polymorpha), which was followed by a decrease in the external nutrient load which slowed the eutrophication rate in the reservoir.

\section{ACKNOWLEDGMENTS}

The authors are grateful to technical staff and students involved in the field measurements, particularly Sebastian Ratajski and Aleksander Góralczyk.

This research was financially supported by the statutory founds of the Faculty of Biology and Environmental Protection University of Łódź.

\section{REFERENCES}

Abraszewska-Kowalczyk A., Jobczyk I., Pazera E. 1999. Zebra mussel Dreissena polymorpha in the Sulejowski Reservoir and the lower Pilica River. Abstracts of the 15th Polish Malacological seminar. Lodz 1999. Folia Malacologica 7 (4): 262.

Allan J.D., Abell R., Hogan Z., Revenga C., Taylor B.W., Welcomme R.L., Winemiller K. 2005. Overfishing of inland waters. BioScience 55 (12): 1041-1051. DOI: 10.1641/0006-3568(2005)055[1041:OOIW]2.0.CO;2

Andrzejewski W., Mastyński J. 2004. Zbiornik zaporowy Jeziorsko - struktura ichtiofauny. [Jeziorsko dam reservoir-structure of the fish fauna.] Archives of Polish Fisheries 12 (Suppl. 2): 35-42. [In Polish.]

Brabrand Å., Faafeng B. 1993. Habitat shift in roach (Rutilus rutilus) induced by pikeperch (Stizostedion lucioperca) introduction: Predation risk versus pelagic behaviour. Oecologia 95 (1): 38-46.

DOI: $10.1007 / \mathrm{BF} 00649504$

Ciepłucha M., Kruk A., Zięba G., Marszał L., Błońska D., Tybulczuk S., Tszydel M., Penczak T. 2016. Regeneracja ichtiofauny rzeki Warty: weryfikacja kategorii zagrożenia gatunków ryb. [Recovery of fish fauna in the Warta River: Verification of the threat categories of fish species.] Scientific Annual of the Polish Angling Association 29: 23-41.

DOI: 10.12823/sapaa.0860-648X.16002 [In Polish.]

Colby P.J., Spangler G.R., Hurley D.A., McCombie A.M. 1972. Effects of eutrophication on salmonid communities in oligotrophic lakes. Journal of the Fisheries Research Board of Canada 29 (6): 975-983. DOI: 10.1139/f72-141

De Backer S., Teissier S., Triest L. 2012. Stabilizing the clear-water state in eutrophic ponds after biomanipulation: Submerged vegetation versus fish recolonization. Hydrobiologia 689 (1): 161-176.

DOI: $10.1007 / \mathrm{s} 10750-011-0902-2$

Eero M. 2004. Consequences of management of pikeperch (Stizostedion lucioperca L.) stock in Pärnu Bay (Baltic Sea) under two different economic regimes, 1960 1999. Fisheries Research 68 (1-3): 1-7. DOI: 10.1016/j.fishres.2004.03.002

Epler P., Kuboszek A., Luszczek-Trojnar E., Socha M., Drąg-Kozak E. 2005. The ichthyofauna of the Goczałkowice dam reservoir in southern Poland in the 1986-2001 period. Archives of Polish Fisheries 13 (2): 267-273.

Frankiewicz P. 1998. Mechanizmy regulacyjne w obrębie zespołu ryb i ich wpływ, poprzez efekt kaskadowy, na jakości wody w nizinnym zbiorniku zaporowym. [Regulatory mechanisms within the fish community and their influence, through the cascading effect, on water quality in a lowland reservoir.] Uniwersytet Łódzki, Łódź, Poland. [In Polish.]

Frankiewicz P., Dabrowski K., Martyniak A., Zalewski M. 1999. Cannibalism as a regulatory force of pikeperch, Stizostedion lucioperca (L.), population dynamics in the lowland Sulejow reservoir (Central Poland). Hydrobiologia 408/409 (0): 47-55.

DOI: 10.1023/A:1017001803791

Frankiewicz P., Dąbrowski K., Zalewski M. 1996. Mechanism of establishing bimodality in a size distribution of age-0 pikeperch, Stizostedion lucioperca (L.) in the Sulejów Reservoir. Annalles Zoologici Fennici 33 (3-4): 321-327.

Gido K.B., Matthews W.J., Wolfinbarger W.C. 2000. Long-term change in a reservoir fish assemblage: Stability in an unpredictable environment. Ecological Applications 10 (5): 1517-1529.

DOI: $10.2307 / 2641301$

Godlewska M., Izydorczyk K., Kaczkowski Z., Jóźwik A., Długoszewski B., Ye S., Lian Y., Guillard J. 2015. Do fish and blue-green algae blooms coexist in space and time? Fisheries Research 173 (1): 93-100. DOI: 10.1016/j.fishres.2015.06.018

Goldyn R., Podsiadłowski S., Dondajewska R., Kozak A. 2014. The sustainable restoration of lakes - towards the challenges of the Water Framework Directive. Ecohydrology and Hydrobiology 23 (4): 1201-1209. DOI: $10.1016 /$ j.ecohyd.2013.12.001

Horpilla J. 1999. Diel changes in diet composition of an omnivorous cyprinid - a possible source of error in estimating food consumption. Hydrobiologia 400 (0): 33-39.

DOI: 10.1023/A:1003746810514

Hrbaček J. 1984. Ecosystems of the European man-made lakes. Pp. 267-290. In: Taub F.B. (ed.) Ecosystems 
of the World 23: Lakes and Reservoirs. Elsevier, Amsterdam, the Netherlands.

Hrbaček J., Albertová O., Desortová B., Gotwaldová V., Popovský J. 1986. Relation of the zooplankton biomass and share of large cladocerans to the concentration of total phosphorus, chlorophyll-a and transparency in Hubenov and Vrchlice reservoirs. Limnologica 17 (2): 301-308.

Kaczkowski Z., Grabowska J. 2016. Problems and challenges of fish stock management in fresh waters of Poland. Pp. 208-215. In: Craig J.F. (ed.) Freshwater fisheries ecology. Wiley-Blackwell, Oxford, UK.

Kakareko T. 2001. The diet, growth and condition of common bream, Abramis brama (L.) in Włocławek Reservoir. Acta Ichthyologica et Piscatoria 31 (2): 3753.

DOI: 10.3750/AIP2001.31.2.04

Kobak J., Kakareko T., Poznańska M. 2010. Changes in attachment strength and aggregation of zebra mussel, Dreissena polymorpha in the presence of potential fish predators of various species and size. Hydrobiologia 644 (1): 195-206.

DOI: $10.1007 / \mathrm{s} 10750-010-0113-2$

Kruk A., Penczak T. 2003. Impoundment impact on populations of facultative riverine fish. Annales de Limnologie-International Journal of Limnology 39 (3): 197-210.

DOI: $10.1051 / \mathrm{limn} / 2003016$

Kubečka J. 1993. [Chapter XI] Succession of fish communities in reservoirs of central and eastern Europe. Pp. 153-168.

DOI: 10.1007/978-94-017-1096-1 11. In: Straskraba M., Tundisi J.G., Duncan A. (eds.) Comparative reservoir limnology and water quality management. Kluwer Academic Publishers Group, Amsterdam.

DOI: 10.1007/978-94-017-1096-1

Kukula K. 2003. Structural changes in the ichthyofauna of the Carpathian tributaries of the River Vistula caused by anthropogenic factors. Supplementa ad Acta Hydrobiologica 4: 1-63.

Lammens E.H.R.R. 1984. A comparison between the feeding of white bream (Blicca bjoerkna) and feeding of bream (Abramis brama). Verhandlungen Internationale Vereinigung für theoretische und angewandte Limnologie 22: 886-890.

Lammens E.H.R.R. 1989. Causes and consequences of the success of bream in Dutch eutrophic lakes. Hydrobiological Bulletin 23 (1): 11-18.

DOI: $10.1007 / \mathrm{BF} 02286423$

Lewandowski K. 2001. Development of populations of Dreissena polymorpha (Pall.) in lakes. Folia Malacologica 9 (4): 171-216.

Mann R.H.K. 1996. Environmental requirements of European non-salmonid fish in rivers. Hydrobiologia 323 (3): 223-235.

DOI: $10.1007 / \mathrm{BF} 00007848$

Marchowski D., Neubauer G., Lawicki Ł., Woźniczka A., Wysocki D., Guentzel S., Jarzemski M. 2015. The importance of non-native prey, the zebra mussel
Dreissena polymorpha, for the declining greater scaup Aythya marila: A case study at a key European staging and wintering site. PLoS ONE. 10 (12): e0145496.

DOI: $10.1371 /$ journal.pone.0145496

Martyniak A., Jerzyk M.A., Adamek Z. 1987. The food of bream (Abramis brama) in the Pierzchaly Reservoir (Poland). Folia Zoologica 36 (3): 273-280.

Mehner T. 2010. No empirical evidence for communitywide top-down control of prey fish density and size by fish predators in lakes. Limnology and Oceanography 55 (1): 203-213.

DOI: $10.4319 / 10.2010 .55 .1 .0203$

Mehner T., Schiller S., Staaks G., Ohlberger J. 2011. Cyclic temperatures influence growth efficiency and biochemical body composition of vertically migrating fish. Freshwater Biology 56 (8): 1554-1566.

DOI: $10.1111 /$ j.1365-2427.2011.02594.X

Molloy D.P., Karatayev A.Y., Burlakova L.E., Kurandina D.P., Laruelle F. 1997. Natural enemies of zebra mussels: Predators, parasites, and ecological competitors. Reviews in Fisheries Science 5 (1): 27 97. DOI: $10.1080 / 10641269709388593$

Nagelkerke L.A.J., Sibbing F.A. 1996. Efficiency of feeding on zebra mussel (Dreissena polymorpha) by common bream (Abramis brama), white bream (Blicca bjoerkna), and roach (Rutilus rutilus): The effects of morphology and behaviour. Canadian Journal of Fisheries and Aquatic Sciences 53 (12): 2847-2861. DOI: $10.1139 / \mathrm{f} 96-229$

Paulovits G., Ferincz Á., Staszny Á., Weiperth A., Tátrai I., Korponai J., Mátyás K., Kováts N. 2014. Long-term changes in the fish community structure of a shallow eutrophic reservoir (Lake Hídvégi, Hungary), with special reference to the exotic Carassius gibelio. International Review of Hydrobiology 99 (5): 373 381.

DOI: 10.1002/iroh.201301662

Persson L. 1986. Effects of reduced interspecific competition on resource utilization in perch (Perca fluviatilis). Ecology 67 (2): 355-364.

DOI: $10.2307 / 1938578$

Persson A., Hansson L.-A. 1999. Diet shift in fish following competitive release. Canadian Journal of Fisheries and Aquatic Sciences 56 (1): 70-78. DOI: 10.1139/f98-141

Piniewski M., Marcinkowski P., Kardel I., Gielczewski M., Izydorczyk K., Frątczak W. 2015. Spatial quantification of non-point source pollution in a mesoscale catchment for an assessment of buffer zones efficiency. Water 7 (5): 1889-1920. DOI: $10.3390 /$ w7051889

Pivnička K., Švátora M. 1977. Factors affecting the shift in predominance from Eurasian perch (Perca fluviatilis) to roach (Rutilus rutilus) in the Kličava Reservoir, Czechoslovakia. Journal of the Fisheries Research Board of Canada 34 (10): 1571-1575.

DOI: $10.1139 / \mathrm{f} 77-220$ 
Prejs A. 1978. Eutrofizacja jezior a ichtiofauna. [Eutrophication of lakes and the ichthyofauna.] Wiadomości Ekologiczne 24 (3): 201-208. [In Polish.]

Prejs A. 1984. Herbivory by temperate freshwater fishes and its consequences. Environmental Biology of Fishes 10 (4): 281-296.

DOI: $10.1007 / \mathrm{BF} 00001481$

Prejs A., Lewandowski K., Stańczykowska-Piotrowska A. 1990. Size-selective predation by roach (Rutilus rutilus) on zebra mussel (Dreissena polymorpha): Field studies. Oecologia 83 (3): 378-384.

DOI: $10.1007 / \mathrm{BF} 00317563$

Prus P. 2009. The dependencies between the abundance of Chironomus f. 1. plumosus and bream (Abramis brama) net catches in a lowland reservoir (Zegrzyński Reservoir, central Poland). Oceanological and Hydrobiological Studies 38 (3): 15-30. DOI: $10.2478 / \mathrm{v} 10009-009-0028-2$

Psuty I. 2010. Natural, social, economical and political influences on fisheries: A review of the transitional area of the Polish waters of the Vistula Lagoon. Marine Pollution Bulletin 61 (4-6): 162-177.

DOI: 10.1016/j.marpolbul.2010.02.010

Ř́ha M., Kubečka J., Vašek M., Sed'a J., Mrkvička T., Prchalová M., Matěna J., Hladík M., Čech M., Draštík V., Frouzová J., Hohausová E., Jarolím O., Jůza T., Kratochvíll M., Peterka J., Tušer M. 2009. Long-term development of fish populations in the Rímov Reservoir. Fisheries Management and Ecology 16 (2): 121-129.

DOI: $10.1111 / \mathrm{j} .1365-2400.2008 .00650 . x$

Scharf W. 2008. Development of the fish stock and its manageability in the deep, stratifying Wupper Reservoir. Limnologica 38 (3-4): 248-257. DOI: 10.1016/j.limno.2008.06.003

Sed'a J., Kubečka J., Brandl Z. 1989. Zooplankton structure and fish population development in the Rimov Reservoir, Czechoslovakia. Archiv für Hydrobiologie Beiheft Ergebnisse der Limnologie 33: 605-609.

Specziár A., Rezsu E.T. 2009. Feeding guilds and food resource partitioning in a lake fish community: An ontogenetic approach. Journal of Fish Biology 75 (1): 247-267.

DOI: $10.1111 / j .1095-8649.2009 .02283 . x$

Stańczykowska A., Lewandowski K., Czarnołęski M. 2010. Distribution and densities of Dreissena polymorpha in Poland. Pp. 119-126. In: Van der Velde G., Rajagopal S., Bij de Vaate A. (eds.) Zebra mussels in Europe. Backhuys Publishers, Leiden, the Netherlands.

Starmach J., Jelonek M. 2001. Specjalistyczna gospodarka rybacka w zbiornikach wodociągowych. [Specialized fishery management in drinking water reservoirs.] Supplementa ad Acta Hydrobiologica 1: 1-25. [In Polish.]

Straškraba M. 1998. Limnological differences between deep valley reservoirs and deep lakes. International Review of Hydrobiology 83 (Special Issue): 1-12.
Szlakowski J., Wiśniewolski W. 2001. Biomasa ryb Zbiornika Zegrzyńskiego w aspekcie ich eksploatacji na przykładzie krąpia Blicca bjoerkna (Linneaus, 1758). [Biomass of fish stocks from Zegrzyński Reservoir as a feature of their exploitation, with a reference to white bream stock, Blicca bjoerkna (Linneaus, 1758)]. Supplementa ad Acta Hydrobiologica 1: 67-76. [In Polish.]

Targońska K., Żarski D., Kupren K., Palińska-Żarska K., Mamcarz A., Kujawa R., Skrzypczak A., Furgala-Selezniow G., Czarkowski T.K., HakućBłażowska A., Kucharczyk D. 2014. Influence of temperature during four following spawning seasons on the spawning effectiveness of common bream, Abramis brama (L.) under natural and controlled conditions. Journal of Thermal Biology 39: 17-23.

DOI: 10.1016/j.jtherbio.2013.11.005

Triest L., Stiers I., Van Onsem S. 2016. Biomanipulation as a nature-based solution to reduce cyanobacterial blooms. Aquatic Ecology 50 (3): 461-483.

DOI: $10.1007 / \mathrm{s} 10452-015-9548-\mathrm{X}$

van den Berg C. 1993. Filter-feeding in common bream (Abramis brama), white bream (Blicca bjoerkna) and roach (Rutilus rutilus); structures, functions and ecological significance. PhD Dissertation, Wageningen University, the Netherlands. http:/ledepot.wur. $n l / 202827$

Wagner I., Izydorczyk K., Kiedrzyńska E., Mankiewicz-Boczek J., Jurczak T., Bednarek A., Wojtal-Frankiewicz A., Frankiewicz P., Ratajski S., Kaczkowski Z., Zalewski M. 2009. Ecohydrological system solutions to enhance ecosystem services: The Pilica River Demonstration Project. Ecohydrology and Hydrobiology 9 (1): 13-39.

DOI: $10.2478 / \mathrm{V} 10104-009-0042-8$

Wiśniewolski W. 2002. Zmiany w składzie ichtiofauny, jej biomasa oraz odłowy w wybranych zbiornikach zaporowych Polski. [Changes in the ichthyofauna composition, biomass and catches in selected Polish dam reservoirs.] Archives of Polish Fisheries 10 (Suppl. 2): 5-73. [In Polish.]

Wiśniewolski W. 2009. Uwarunkowania i prowadzenie gospodarki rybacko-wędkarskiej w zbiornikach zaporowych. [Conditions for the fisheries and angling management in dam reservoirs.] Scientific Annual of the Polish Angling Association 22: 141-161. [In Polish.]

Wiśniewolski W., Borzęcka I., Buras P., Szlakowski J., Wołos A. 2004. Odłowy wędkarskie i sieciowe - wzajemne relacje na przykładzie zbiorników zaporowych Zegrzyńskiego i Siemianówki. [Angling and commercial catches - interrelations, exemplified using the Zegrzyński and Siemianówka dam reservoirs.] Archives of Polish Fisheries 12 (Suppl. 2): 127-147. [In Polish.]

Wojtal A., Frankiewicz P., Izydorczyk K., Zalewski M. 2003. Horizontal migration of zooplankton in a littoral zone of the lowland Sulejów Reservoir (Central Poland). Hydrobiologia 506-509 (1-3): 339-346. 
DOI: 10.1023/B:HYDR.0000008627.55462.e1

Wojtal A., Frankiewicz P., Wagner-Lotkowska I., Zalewski M. 2004. The evaluation of the role of pelagic invertebrate versus vertebrate predators on the seasonal dynamics of filtering Cladocera in a shallow, eutrophic reservoir. Hydrobiologia 515 (1-3): 123135.

DOI: 10.1023/B:HYDR.0000027324.44452.9e

Wojtal-Frankiewicz A., Kruk A., Frankiewicz P. Oleksińska Z., Izydorczyk K. 2015. Long-term patterns in the population dynamics of Daphnia longispina, Leptodora kindtii and Cyanobacteria in a shallow reservoir: A Self-Organising Map (SOM) approach. PLoS ONE 10 (12): e0144109.

DOI: 10.1371/journal.pone.0144109
Wołos A., Piskorski P. 1991. Anglers' catches as an illustration of the fish community structures, angling pressure and angling regulations based on inland waters in Krosno Region, Poland. Pp. 166-176. In: Cowx I.G. (ed.) Catch effort sampling strategies. Their application in freshwater fisheries management. Fishing New Books, Blackwell Scientific Publications, Oxford, UK.

Zalewski M. 1998. Ecohydrology and fisheries management. Italian Journal of Zoology 65 (Suppl. 1): 501-506.

DOI: $10.1080 / 11250009809386874$

Received: 3 January 2017

Accepted: 1 August 2017 Published electronically: 30 September 2017 